\title{
THE FEDERAL JUDICIARY IN BRASIL AND THE UNITED STATES OF AMERICA.
}

The Federal Union of the Brasilian government, under the title of "The United States of Brasil" was established by the Constitution of February 24, 189i, the first article of which reads as follows:

"The Brasilian Nation adopts for its government the federal republican representative form, as proclaimed on the fifteenth of November eighteen hundred and eighty nine, and constitutes itself, by the perpetual and indissoluble union of its former provinces, into the United States of Brasil."

According to this constitution, the Federal government shall be exercised by the President of the Republic, the National Congress, composed of the House of Deputies and the Senate, and the judicial power, vested in a Federal Supreme Court and several inferior Federal courts. -These powers of the Federal government are declared by the constitution to-be "the organs of the national sovereignty;" and it is further stated that they shall be harmonious with each other, and independent among themselves.

The Brasilian Federation is composed of twenty states and the District of Rio de Janeiro (Federal District), which is the seat of the Federal government.

There exist two sets' of courts, namely, the Federal courts and the state courts. The former are created and regulated by the Federal Constitution itself, or by the legislation of Congress; the latter, by the Constitution and laws of the states. As to these two fields of jurisdiction, it is to be observed in general, that the Federal courts have cognizance of those cases only, which the Federal Constitution and the laws of Congress have conferred exclusively upon them, and that the state courts have general common law jurisdiction of all cases under the civil and criminal law, except those cases declared to be within the special cognizance of the Federal courts. In the administration of justice, the Federal District is considered a state. It has, therefore, its 
own courts, which exercise the same exclusive jurisdiction over civil and criminal cases as do the state courts. There are also territorial courts in the "Territory of Acre," the creation, organization and jurisdiction of which depend wholly upon the action of Congress.

The Brasilian Federal Courts are the subject of a number of Constitutional provisions. Article 55 provides that the judicial power of the Union shall be vested in a Federal Supreme Court, which shall hold its sessions in the capital of the Republic and in as many inferior Federal couxts and tribunals, distributed throughout the country, as Congress may create. It is also enacted that the judges and courts of the Union shall have exclusive jurisdiction over:

I. Suits in which either party bases his action or defense on some provision of the Federal constitution;

2. Suits against the Federal government or treasury, founded upon provisions of the Constitution, laws, or executive regulations, or upon contracts entered into with the Federal government;

3. Claims for compensation, recovery of property, indemnification for damages, or any other claims, presented by the government of the Union against private individuals or vice-versa.

4. Suits between one state and the citizens of another, or between citizens of different states, whenever the respective state laws are different;

5. Suits between foreign states and Brasilian citizens;

6. Actions instituted by foreigners, founded upon contracts with the government of the Union or upon conventions or treaties between the Union and other nations;

7. Admiralty and all questions arising out of the navigation of inland waters;

8. Questions of international law and criminal and civil cases arising under the provisions of the Constitution and laws of the Federation;

9. Political crimes.

At the same time Congress is forbidden to delegate any. Federal jurisdiction to the courts of the states. Judgments and decrees of the Federal courts are enforced by Federal court officers, to whom the local police are bound to render assistance when 
called upon to do so. ${ }^{1}$ The judgments of the state courts having competent jurisdiction are final in the suits in which they are rendered, except in cases of habeas corpus, and settlements of estates of a deceased foreigner whenever the case is not provided for by convention or treaty. In such cases there may be an appeal to the Federal Supreme Court. ${ }^{2}$

The state courts have no power to interfere in questions submitted to the Federal tribunals, or to annul, alter, or suspend the judgments or decrees of the latter. And reciprocally, the Federal courts cannot intervene in questions submitted to the state courts, or annul, alter, or suspend the judgments or decrees of the latter. except in the cases expressly defined in the Constitution. ${ }^{3}$ In cases involving the application of the laws of the state, the Federal courts consult the decisions of the local tribunals; and vice-versa, the state courts consult the decisions of the Federal tribunals, when the interpretation of the laws of the Union is involved."

Before the adoption of the Constitution, a decree (October II, 1890) of the Provisional Government of the Republic had been drawn up, creating the Federal judiciary and its jurisdiction. According to the provisions of this decree, which continued in force, the administration of Federal justice was conferred upon the Federal Supreme Court, the judges of Federal sections, of which there was one for each state, and of the Federal District (there are now two judges in the Federal District), and of the Federal Court of Assises.

The Federal Supreme Court is composed of fifteen judges (ministros) appointed by the President of the Republic, with the consent of the Senate. They must be citizens of notable learning and reputation, who are eligible to the Senate. The President of the Republic also appoints, from among the judges, the AttorneyGeneral, whose duty, as chief law officer, is, in general, to watch over the due application of the Federal Constitution and laws, to defend and control the interests of the Union before the

\footnotetext{
${ }^{2}$ Constitution, Article 6a.

- Constitution, Article 6r.

- Constitution, Article 6a.

- Constitution, Article 59, sec. 2
} 
Federal Supreme Court in all suits in which the Federation is a party, and to exercise other important duties imposed upon him by the Federal law. The Supreme Court chooses its President and $V$ ice-President from among its own members for a term of three years. These officers are eligible for re-election. The judges of the Federal sections, sitting in the capital of each state, are appointed by the President of the Republic upon tlie recommendation of the Federal Supreme Court, which suggests the names of three citizens, who, besides other required qualifications, have obtained the degree of doctor or bachelor of laws in 2 Brasilian University, and who have practiced as attorney or counsellor at law for at least two years. The President likewise appoints for a term of six years a substitute judge for each judge of a Federal section. It is the duty of the former to assist the latter in certain proceedings, as prescribed by law, and to take his place in case of temporary disability, until he is able to perform the duties of his office. There exist also in each judicial section a Federal district-attorney and several assistant attorneys, also appointed by the President of the Republic, whose principal duty is to prosecute all delinquents for crimes and offenses cognizable in the Federal courts and to appear in all civil actions with which the Union or the Federal Treasury may be concerned. The Federal jury is composed of the judge of the Federal section as its president, and twelve jurors drawn by lot from among a list of forty-eight citizens, who have been registered to serve as jurors in the capital of each state. The services of a juror are gratuitous; and only Brasilian citizens can sit as jurymen. The Federal jury meets periodically. It takes cognizance of criminal cases only; and the votes of a majority of the jurors are necessary to acquit or convict.

The jurisdiction and powers of the Federal Supreme Court are adequately provided for in the Constitution. It has:

I. Original and exclusive jurisdiction over:

I. The President of the Republic for ordinary crimes, and the ministers of state in certain cases specified in Article 52 of the Constitution.

2. Ordinary crimes of which the diplomatic representatives are accused; and cases of impeachment. 
3. Disputes and conflicts between the Enion and the states, or between the several states.

4. Suits and claims betwcen foreign nations and the Union, or between foreign nations and the states.

5. Conflicts between the Federal jutges or courts, or bebetween them and those of the states; and conflicts of the judges and courts of one state with the judges and courts of another state.

II. Appellate jurisdiction orer questions passed upon by the inferior Federal courts, as well as those arising upon the writ of habeas corpus and upon the settlement of the estate of a deceased foreigner.

III. Power to review any criminal sentence upon the instance of the accused.; The law shall determine the manner andform of the revies which may be asked for, either by the condemued party, by any citizen third party, or ex officio by the Attorney-General of the Republic. In such revisions, the pen--: alties imposed by the judgment under review shall not be increased. These prorisions are also applicable to military trials."

Appeal to the Federal Supreme Court may also be taken from the decisions rendered in the last instance by the courts of the states:

1. When the validity of laws or acts of the states as.opposed to the Federal Constitution or laws, is questioned, and the state court shall have decided in faror of the validity of the state acts or laws in question.

2. When the validity or application of the Federal laws or treaties is called in question and the decision of the state court shall be against the same.

Congress cannot alter or enlarge the original jurisdiction nor modify the appellate jurisdiction of the Federal Supreme Court, as specified in the Constitution. Nevertheless, it has been admitted, that Congress may confer upon the same court an appellate jurisdiction over new cases, although not specified in the Constitution itself. The decisions of the Federal Supreme Court

\footnotetext{
- Constitution, Articles 59 and 6r.

- Constitution, Article 8r.
} 
cannot be modified, altered, suspended or reversed, but by the court itself and as prescribed by law.

The Federal Supreme Court also decides all questions as to the extent of its own jurisdiction.

Furthermore it has special power:

I. To issue writs of habeas corpus on original petition of the prisoner, or on review of the decision of any Federal or state court.

2. To make court rules of practice.

3. To provide for a court clerk.

4. To administer the oath to the President of the Republic upon his entering office, if Congress is not in session.

The President of the court has the power:

I. To appoint the clerk and the other officers of the court.

2. To grant leave of absence, for a term not exceeding four months, to the associate members of the court, and any Federal judge or officer. .

3. To preside over the Senate, in the latter's chamber, when constituted a court of justice in impeachment cases.

4. To exercise the office of the President of the Republic in case of the temporary disability of that officer; or of the Vice-President, President pro-tcmpore of the Senate, or President of the House of Deputies.?

The judges of the Federal sections have general jurisdiction, in the first instance, of all cases and proceedings, which the Federal Constitution, by its sixtieth article, confers upon the Federal judiciary, except the causes and proceedings specifically reserved to the original cognizance of the Federal Supreme Court. Thus the courts of Federal sections have jurisdiction over all civil and criminal cases arising under the Fcderal Constitution and laws, except over those criminal cases to which the Union is a party; all cases arising under the Federal patent-right and copyright laws; all suits brought against acts of Federal officers on the ground of violation of individual rights or privileges, for the purpose of annuling such acts and recovering indemnification for damages; impeachment proceedings against attorneys of the Republic and other Federal public officers residing in the re-

\footnotetext{
'Constitution, Article 59, sec. ta.
} 
spective sections; and petitions of habeas corpus, where the prisoner is held in custody for crimes committed under the Federal law. The judges of the Federal sections have jurisdiction to pass upon certain stipulated crimes without the intervention of a jury.

Each judge of a Federal section is empowered to issue the proper orders for the execution of the judgments and decisions of the Federal Supreme Court within the territory of his own section. He has also the power to appoint the necessary officers and employees of his court. The Federal judges hold office for life and are removable only by judicial sentence. They receive for their services a salary or compensation, which, orice fixed by the law, cannot be diminished. In cases of impeachment the Senate tries the judges of the Federal Supreme Court, who in turn try all Federal inferior judges. When a judge of any Federal court becomes permanently unable to perform his duties, he is removed from office and receives a life pension of one-half his salary, if he has been in office during a period of ten years. If he has held office for twenty years or longer, he receives full salary upon retirement. For the purpose of claiming such a pension a judge may utilize, to his benefit, any period which he may have spent in public service, in whatever department of the government. But no Federal judge is allowed to exercise other public functions during his continuance in office.

Between the Brasilian judiciary and the American judiciary, there exist several differences, notwithstanding the fact that the former has been modeled upon the latter. Of these the most noticeable will be indicated.

The American District Courts are in respect of their organization wholly similar to the Brasilian Courts of Federal sections. But in the judicial system of Brasil there are no such courts as the "Court of Claims," the "Circuit Courts of Appeals," the "Court of Customs Appeals" and the "Commerce Court"

The necessity of an appellate court standing between the courts of the Federal sections and the Federal Supreme Court, for the purpose of lessening the burden of litigation resting upon the latter, has also been felt in Brasil, for it is an acknowledged 
fact that the Supreme Court finds itself continually behind in the hearing of the ever accumulating mass of appeals to its jurisdiction. To remedy this embarrassing inconvenience, a bill is now pending in the National Congress for the creation of Federal courts of appeals throughout the country, entirely similar to the Circuit Court of Appeals existing in the United States. But no suggestion has yet been made for the creation of such courts as the Court of Customs Appeals, and the Commerce Court; and such courts may perhaps be deemed unnecessary, in view of the general jurisdiction conferred upon the courts in the Brasilian judicial system.

There is not in Brasil any special equity court or procedure. All Brasilian courts are courts of law, but they administer the rules and principles of equity, as found in the body of English and American jurisprudence.

In regard to the organization of the Federal Supreme Court of Brasil, it is to be observed that the Constitution has fixed the number of its members, while the American Constitution has left to Congress, at its discretion, the organization of the Supreme Court of the United States. This, in the opinion of an eminent writer, constitutes a weakness in the latter court's armor, through which a weapon may some day penetrate. Nobody, as Mr. Bryce says, can rely absolutely upon the stability of certain decisions of the United States Supreme Court as being final, for Congress may pass a statute, increasing or diminishing the number of its justices; and the new majority may disapprove the earlier decision. The history of the American Supreme Court presents instances of this danger in the decisions on paper as legal tender for debts, rendered in 1870,1871 and 1884 . The fathers of the Constitution studied every means of securing complete independence to the judiciary; but, as we see, by altering the number of judges, the executive and Congress may influence its decisions. Let us suppose, for example, that Congress and the President are bent upon passing a law which the Supreme Court deems contrary to the Constitution. The statute in question is enacted, and a case arises under it. The court on hearing the case, unanimously declares that Congress did not have power 
to enact the measure, which is, therefore, null. Congress forthwith passes, and the President signs, another statute more than doubling the number of the justices. The President appoints new judges who are pledged to hold the former statute constitutional, and the Senate confirm his appointments. Another case raising the validity of the disputed statute is brought up to the court. The new judges out-rote the old ones; the statute is held valid; and the security provided for the protection of the Constituium is gone, like a morning mist. ${ }^{8}$ In Brasil such assaults on the clecisions of the Supreme Court are prevented, because of the provisions of the Constitution, which cannot be altered by any ordinary legislation of Congress.

In Brasil the Federal Supreme Court has a President (Chief Justice) and a Vice-President, elected by the court itself from among its members for a period of three years, and eligible for re-election. In America, the President of the United States appoints the Chief Justice, who retains that title so long as he remains on the Supreme bench.

In Brasil, the President of the Supreme Court has the power, not only to appoint and remove, at his discretion, all administrative officers of the court, but to grant leaves of absence, not exceeding four months, both to the federal judges and to the officers of the federal courts in general. In America, the Chief Justice does not possess such extensive powers.

In Brasil, the Attorney-General is appointed by the President of the Republic from among the judges of the Supreme Court; and although such judge continues to sit in the court, he is without the right of voting during the term of his service as Attorney-General. The Attorney-General shall have charge and conirol of all interests of the Union in all cases and proceedings in the Supreme Court, both in those of an original nature and in those brought by appeal or writ of error from any court below. In America, on the other hand, the Attorney-General holds office by virtue of his appointment by the President; and although he discharges duties in the Supreme Court very similar to those of the Brasilian Attorney-General, he cannot be considered a mem-

"I Bryce, "The American Commonwealth," ch. XXIV. 
ber of the court. On the contrary, he appears before the court as a high executive officer, the head of the Federal Department of Justice.

In the matter of the jurisdiction vested in the Federal courts, there are again no differences between the American and the Brasilian judiciane? For example, in Brasil, there is no such jurisdiction, concurrent in both Federal and state courts as exists in the United States. The jurisdiction rested in the Brasilian Federal courts, on the contrary is without exception an exclusive one. Concurrent jurisdiction, it is believed, notwithstanding appropriate rules governing the subject, may lead to collisions, and sometimes to dangerous disputes between the Federal and state courts. In order to obviate any such result in the administration of justice, Congress was forbidden by the Constitution itself, to pass any act assigning to state courts any power concerning matters of Federal cognizance; and vice-versa, to assign to Federal courts, power over subjects within the purview of the state courts. Therefore, if it happens that a suit properly of Federal cognizance is brought in a state court, the defendant has a right either to apply for the removal of the case to the competent Federal court, before the trial thereof; or. by writ of error, to apply for the nullification of all proceedings, after final judgment of the cause in the state court, upon the ground of want of jurisdiction, such a question being admittedly a Federal one under the decisions of the Brasilian Federal Supreme Court.

The removal of a cause is granted by the Supreme Court, either by a special writ called "Aggravo" (very similar to "certiorari" in the American judicial practice), or by an appropriate proceeding called "Conflict of jurisdiction," which is certified to the Supreme Court upon petition of any party to the suit, or upon the certification of the court below, itself.

Both the American and the Brasilian Federal Constizutions have pointed out the subjects orer which the judicial power shall extend. But in the provisions of the latter are contained matters which either are not, or are to a less extent, comprehended in the provisions of the former. For instance, the Brasilian Constitution includes in the grant of Federal jurisdiction the cognizance 
of all questions of public and private international law, and of all political crimes.

The reason for including in the field of Federal jurisdiction, international law affecting the private citizen, is that the application of the rules and principles of private international law are of the utmost importance in foreign relations. The solution of questions arising out of such relation:s is, therefore, more safely to be intrusted to the national than to local courts. Of course, according to the American Constitution, questions arising under the treaties made under the authority of the United States, and controversies between a state or citizen thereof and foreign states or their citizens or subjects, fall within the Federal jurisdiction. But proof that private international law, as a criterion, does open a broader field than that assigned to the Federal courts by the American Constitution, is found in the fact that state courts are frequently called upon to hear and settle cases respecting matters undoubtedly pertaining to the province of private international law. This province, it will be adnitted, embraces the questions growing out of the "conflict of laivs," that is, such controversies as may arise by virtue of the fact that different persons, things and acts have their situs in different countries. As a rule the main problem in such disputes is to determine whether the national law or the law of a foreign country shall be applied to the case before the court. It is manifest that great inconvenience may result from the fact that two independent sets of courts are permitted to have concurrent jurisdiction over such questions, often reaching exactly opposite conclusions.

Political crimes may be committed, either against the Federal government and its officers, or against state governments. As to the former, no reasonable doubt can be raised, that they should be, by their nature, properly subject to Federal jurisdiction. As to the latter, the chief reason for giving the Federal courts jurisdiction is to secure an impartial tribunal, since there is danger that the accused, from local prejudice, or influence on the part of state authorities, will not be able to obtain a fair trial in the state court. 
The American constitutional provision enumerates only the matters over which the Supreme Court shall have original jurisdiction, namely, the cases affecting ambassadors, other public ministers and consuls, and those in which a state shall be a party; in all other cases, the Supreme Court has appellate jurisdiction under such regulations as Congress shall make. The Brasilian Constitution, on the other hand, enumerates not only the subjects of the original exclusire jurisdiction of the Federal Supreme Court, including therein matters not mentioned in the grant of powers to the American Supreme Court, but it does the same respecting the subjects of the appellate jurisdiction of the court. Hence, undoubted as is the power of the Brasilian Congress to legislate on such matters of procedure as it deems wise to regulate, it cannot alter or change the subjects of the jurisdiction of the Supreme Court, as provided for by the Constitution itself. For example, in the provision of the Brasilian Constitution respecting the original jurisdiction of the Supreme Court are included the trial of the President of the Republic and of his ministers for ordinary cr.mes and the impeachnent of the latter as prescribed in Article 52 of the Constitution; and conflicts between the Union and the states, or between the states one with another, that is, conflicts over the scope of authority of executive or adminisrative officials of Federal and state governments, or between officers of different states. Such subjects are not expressly mentioned in the provisions of the American Constitution.

Foreign judgments and extradition are other matters over which the Federal Supreme Court of Brasil has exclusive jurisdiction. On the other hand, no such peculiar powers are conferred upon the Supreme Court of the United States.

In Brasil, as in sereral European countries, foreign judgments may be declared executory, that is, to have the force of "res judicata." During the time of the Empire such declaration was obtained by an act of the Government, called "excquatur." Since the Empire, it has been understood that the discharge of such functions belongs, from the judicial nature of the matter, to the highest national court. Therefore, the Supreme Court is ex- 
clusively competent to grant "Homologation" of all foreign judgments, even in the absence of a treaty concerning the subject, provided that the judgments were rendered under the conditions required by Brasilian law. These conditions require that the foreign court must have had jurisdiction of the case in question; that the interested parties must have been duly summoned; that the judgment must be final; and that the judgment should not contain any provision or clause repugnant to the Brasilian public law.

In Brasil, as in America, the requisition for extradition should come from the supreme political authority of the demanding state, and be addressed to the Secretary of State. But surrender of an individual accused or convicted of an offense outside of the Brasilian territory cannot be granted without a previous decision upon the subject matter by the Federal Supreme Court. The accused must be brought with all the requisition papers to the Federal Supreme Court, which, after hearing the defense, pronounces whether the extradition shall or shall not be granted to the demanding state. Such decision is final, and cannot be reviewed in any way.

It is further to be observed, that the American Constitution grants Federal jurisdiction in "all cases arising under the Constitution, the laws of Congress, and the treaties made under the authority of the United States;" that is to say in every case, where a party to the suit inrokes Federal law in his behalf. The Brasilian Constitution does not go so far. It extends Federal jurisdiction only to those cases arising expressly or impliedly, from the provisions of the Constitution. The reason for this limitation is that the body of the substantive laws, civil and criminal, is enacted by the national Congress, and not by the state legislatures, as in the United States. The legislative power of the states of the Brasilian Union is limited to the enactment of such laws of procedure, as is necessary for the transaction of the business of the state courts. It is therefore plain, that if all cases arising under the Federal law fell equally within the jurisdiction of the Federal courts, the state courts would have prac- 
tically no function. The law, therefore, declares the special subjects, over which the Federal courts shall entertain jurisdiction, in order to avoid conflicts of jurisdiction between the two sets of courts.

It is well known that the.Supreme Court of the United States in the case of Chisholm $v$. Georgia decided that under the Constitution a citizen of one state might sue another state in a Federal court. This decision gave rise to the eleventh amendment of the Constitution, whereby it is provided, that the judicial power of the United States shall not be construed to extend to any suit in law or equity against one of the United States by citizens of another state, or by citizens or subjects of any foreign state. And it is the settled construction of this amendment, that the exemption from suit growing out of the sovereignty of a state is not deemed waived in a grant of Federal judicial power except in cases specifically mentioned. ${ }^{\text {I }}$ In the Brasilian system the opposite principle prevails. There any state of the Union may be sued in the Federal courts by citizens of another state, or by citizens or subjects of any foreign state, or even by citizens of the same state, in like manner as any other party before such a court.

This is perhaps the most important difference between the Brasilian and the American judiciary. The theory on which the law of the United States' Constitution rests, is the ancient English doctrine that "the state, ${ }^{10}$ because of its sovereignty, is not suable without its consent." Story expresses this same doctrine in these words:

"As to private injustice or injuries, they may regard either the rights of property or the rights of contract, for the national government is per se incapable of any merely personal wrong, such as an assault and battery, or other personal violence. In regard to property, the remedy for injuries lies against the immediate perpetrators, who may be sued, and cannot shelter themselves, under any imagined immunity of the Government, from due responsibility. If, therefore, any agent of the Government

\footnotetext{
- Rose's Code, sec. 7 .

"The term "state" is here used in its general sense, as importing the Union or one of its federated members.
} 
shall unjustly invade the property of a citizen under color of a public authority, he must, like every other violator of the laws, respond in damages. . . . The greatest difficulty arises in regard to the contracts of the national government; for, as they cannot be sued without their own consent, and as their agents are not responsible upon any such contract when lawfully made, the only redress which can be obtained must be by the instrumentality of Congress either in providing (as they may) for suits in the common courts of justice to establish such claims by a general law, or by a special act for the relief of the particular party. In each case, however, the redress depends solely upon the legislative department, and cannot be administered except through its favor. The remedy is by an appeal to the justice of the nation in that forum and not in any court of justice, as a matter of right." 11

The principles governing Brasilian jurisprudence on the matter may be briefly stated in this way: Even assuming that the Union or the state in its sovereign aspect is not suable in any court, it is, nevertheless a well known fact that the state does not perform only duties or powers incident to its sovereignty. On the contrary, we know that the state is or may be a proprietor of real estate and chattels, a manager of post and telegraph services, a proprietor or incorporator of bank and railway companies, a stockholder in railroads and the like, a proprietor of public deposits or storehouses (such as custon houses) or a party to contracts of various kinds entered into with private individuals. And it is obvious, that in all the situations growing out of such relations, the state does not act in its sovereign character. It acts merely as a public corporation, a civil person. It should therefore be liable under the particular law governing the consequences of the acts of private persons under like conditions. Furthermore, the state regarded as a "Public Administrator," may violate, through the agency of its numerous officers, legal rights of individuals; rights sometimes founded upon the Constitution or the statutory law of the land.

Why, therefore, should the courts refuse redress to the injured party? They have been established for the precise pur-

"Story on the Constitution, sec. 1677. 
pose of recognizing the violation of individual rights; and it is unreasonable to assert that the state, which protects the rights of individuals by providing appropriate remedies against violations thereof, has the power to refuse such remedy, where the wrong complained of was committed by the state itself. Besides, it is plain that the English doctrine is manifestly in opposition to another great principle of English jurisprudence, namely, "that where there is a legal right, there is also a legal remedy by suit or action at law, whenerer that right is invaded." 12

The modern state, in spite of its sovereignty, has no longer, as had the ancient state, a despotic authority-"sic volo, sic jubco; sic pro ratione zoluntas." It is now a creation of the law, namely of the Constitution, which is the fundamental creator of all duties, rights and privileges, conferred upon the state. By virtue of the powers so vested in the state, it is authorized to enact laws necessary and proper for the protection of the rights of all individuals within its territory. But no political or moral principle, no rule of propriety, of policy or of justice, can be invoked by virtue of which the state is entitled to violate the rights of individuals on the pretext of its sovereignty. Even in England, where the rule that "The king can do no wrong" still prevails, it has been established that "Rc.x dcbet csse sub lege, quia lex facit regcm," the king is subject to the law, for law makes the king. ${ }^{13}$

Justice in modern states is so essential to national life and its relation to the individual, that notwithstanding the settled rule of the non-responsibility of the United States before the courts, Congress has authorized suits against the government in a great variety of cases, and has vested jurisdiction thereof in the Court of Claims and the District Courts, and sometimes in the Supreme Court, depending on the nature of the subject matter, its value, or the character of the parties to the suit. But the jurisdiction granted to the courts in these cases is limited to the conditions specified in the provision granting jurisdiction. And it has been held, that whenever Congress chooses to withdraw from such

\footnotetext{
"Blackstone, Comm., Bk. IIL.

"Blackstone, Comm., Bk. $\mathbf{L}$.
} 
jurisdiction any class of cases which had before been included therein, it has the power to do so; and no reason can be perceived why Congress may not at any time withdraw a particular case from the cognizance of the respective court, or prescribe in such case the circumstances under which alone the court may render a judgment against the Government. ${ }^{14}$ Moreover, as has been seen, the admission of actions against the United States, when brought by private individuals in the courts, is to be considered as a favor granted by Congress rather than as a matter of right in the plaintiff. It is further to be noted that Congress has never allowed suits sounding in tort to be brought against the government. Hence the remedies of individuals against the government are limited to suits founded upon the Constitution, a law of Congress, any regulation of an executive department, or any claim of a disbursing officer of the executive department, as provided by law, and on other controversies $c x$ contract $u$. It is not apparent why Congress was not equally willing to subject the government of the Union to suit in cases of torts by its officers in the performance of their duties or public functions, as well as for violation or breach of contract. For individual rights may be transgressed tortiously as well as ex contractu, by officers of the government under color of Federal authority.

In the Brasilian jurisprudence, as stated, there is no limitation of this kind in the grant of jurisdiction to the courts. The rule is that "Where a legal right of the individual is violated, there is also a legal remedy by suit or special proceeding in the courts." Whether the violator is the Union or any state of the Union makes no difference; the rule applies with equal force. The Union or the state must, like any other violator of the laws, respond in damages, unless the law itself establishes special exception thereto. Individual rights of property and person, though defined by the state in its discretion or sovereignty, when embodied in the law actually in force, bind not only individuals in their mutual relations, but to a like extent, the state. "Ubi eadem ratio, ibi idem jus."

"De Groot v. United States, 72 U. S. 419 
It is a settled principle of universal jurisprudence, that he who acts through the agency of another acts by himself. "Qui facit per alium, facit por se." The agent is deemed to transact the business, or to perform his duties, by the authority and on account of his principal. Accordingly, nothing is more reasonable and just, than that he who obtains profits, services and advantages through his agent or employee, ought to be responsible for the agent's acts if they injure a third party. "Cui beneficium, cui onus." This doctrine is now received in American jurisprudence with regard to private corporations and, with certain exceptions, with regard to municipal corporations. In relation to private corporations, Cooley says:

"It was formerly supposed that those torts, which involved the element of eril intent, such as batteries, libels and the like, could not be committed by corporations, inasmuch as the state, in granting rights for lawful purposes, had conferred no power to commit unlaw ful acts; and such torts, committed by corporate agents, must consequently be ultra vires, and the individual wrongs of the agents themselves. But this idea no longer obtains. - . - To deny redress against the corporations would, in many cases, be a denial of all remedy. . . . The rule is now well settled that, while keeping within the apparent scope of corporate powers, corporations have a general capacity to render themselves liable for torts, except for those where the tort consists in the breach of some individual duty-which from its nature could not be imposed upon or discharged by a corporation." 16

\section{Likewise, Elliot says:}

"It is now the settled law, that a corporation is liable civiliter for torts committed by its agents or servants precisely as a. natural persori. - . - When an officer does an act which is within the general scope of his powers, although circumstances may exist which render the particular act a violation of his duty, the corporation is nevertheless bound by his acts as to persons dealing in ignorance of those circumstances, and is responsible to innocent third parties who have sustained damages occasioned by such acts. - . . The liability of a corporation for the consequences of acts of its officers, done within the scope of their general powers, is not affected by the fact, that the act which the

I Cooley on Torts, igg. 
officers have assumed to do, is one which the corporation itself could not rightfully do. A corporation. like an individual, may do wrong through its agents and be liable for the wrongful act. The liability extends to torts involving a specific intent, or element of malice, as fraud, malicious wrong, hibel, malicious prosecution or conspiracy." 16

As to municipal corporations, the rule to be applied is expressed by judge Dillon, as follows:

"The doctrine may be considered as established, that where a duty is a corporate one. that is, one which rests upon the municipality in respect of its special or local interests, and not as a public agency, and is absolute and perfect, and not discretionary or judicial in its nature, and is one owing to the plaintiff, or in the performance of which he is specially interested-that the corporation is liable in a civil action to perform the duty, or for the want of proper care or want of reasonable skill of its officers or agents, acting under its direction or authority in the execution of such a duty; and with the qualifications stated, it is liable, on the same principles and to the same extent, as an individual or private corporation would be under like circumstances." 17

There is no reason why the civil responsibility of the state should be governed by different principles of justicc in cases where the state acts as an administrative corporation. The contention that the state is beyond the sphere of private law cannot longer obtain. The state is already subject to the provisions of private law in case of breach of contract and other civil obligations. Instend of maintaining the vicious maxim that "the sovereign can do no wrong," it should be recognized as a fact that "the state may do wrong;" and, accordingly, it onght to respond in damages to any party injured by its wrong. - Another argument in favor of the liability of the government to the individual is found in the uncertainty of the financial responsibility of the officers of the government who perpetrate the wrong. At any rate, judicial redress against the government itself is far more reliable.

28 Elliott, Private Corporations, sec. 234.

${ }^{27}$ Dillon on Municipal Corporations, sec. 980 
Of course, the general jurisdiction of the Brasilian courts over suits in which the Lnion is a defendant, as well as when it appears as plaintiff, does not negative the possibility of an exemption or immunity specifically granted by law in its favor. That which is, in the Brasilian jurisprudence, deemed essential to the protection of individual rights, is that it shall belong to the court of competent jurisdiction, not to the government, to examine the particular case, and give judgment against the Union if it finds the legal right to be with the claimant; that the responsibility of the Union for damages for failure to perform a duty on account of a manifest violation of a legal right of the individual, ceen sounding in tort, committed by the administrative officers of the Union under color of its authority, may be pronounced by the competent court; and that such responsibility of the Union does not exclude the joint liability of the officer, as provided by law or by the regulations of the Executive Department. Such is, upon the whole, the Brasilian judicial ductrine on this so important matter. This doctrine has resulted from a deep national feeling that the administration of justice would be plainly imperfect if an indiviclual right could be invaded, without a judicial remedy granted to the injured party, not as a favor, but as a matter of right.

Rio Janeiro, Brasil. 